\title{
The Evolution of Russian Conceptual and Political Models of High Technology Cooperation with Foreign Nations and Multinational Corporations
}

\author{
Ivan V. Danilin *
}

International cooperation in the area of high technology—in design and development, manufacturing, and distribution - is one of the most important features of the current state of innovation around the world. Outsourcing, the ability to search for talent globally, the lowering of costs by transferring production facilities to developing countries, the evolution of global supply chains, venture capitalists' tireless search for fresh ideas all over the world - all these and numerous other processes combine to shape the reality of modern highly internationalized, collaborative, and interconnected activities involved in developing innovative new technologies. ${ }^{1}$ Even during the recent global economic crisis, these trends persisted. In spite of the fact that Western multinational corporations (MNCs) dominate the market and still are key players in these processes, companies from China and other developing nations are actively joining the game. ${ }^{2}$ Russia, which has declared its intention to regain (on a new footing) its former leadership role in science and technology, is also looking at international cooperation in the area of high technology as a powerful and important instrument for the development of national networks of innovation and a strong innovative economy, in hopes of securing a significant future market share in global sales of high-technology goods and services. But unlike many other nations, Russia's path, strategies, and modes of cooperation are still in transition, and are affected not only by the logic of the globalized economy, but also by different political and economic challenges inherited from previous decades, as well as by the political visions of different groups of national elites.

Ivan V. Danilin is the Head of Division of the Institute of World Economy and International Relations in the Russian Academy of Sciences, and an associate professor at the Moscow State Institute of International Relations. This article was made possible by a grant from the Russian Foundation for Basic Research (RFFI), Project \#09-06-00362-a. The author gratefully acknowledges helpful comments from Irina Dezhina (IMEMO) and Laura Roselle (Elon University) on earlier versions of this article.

1 OECD Science, Technology and Industry Outlook 2008 (Paris: OECD, 2008); OECD Science, Technology and Industry Scoreboard (Paris: OECD, 2009); National Science and Engineering Indicators 2010 (Arlington, VA: National Science Board, 2010); United Nations Conference on Trade and Development, World Investment Report: Transnational Corporations and the Internationalization of $R \& D$ (New York: United Nations, 2005), also published in Transnational Corporations 14:3 (December 2005): 101-40.

OECD Reviews of Innovation Policy. China: Synthesis Report (Paris: OECD, in collaboration with the Chinese Ministry of Science and Technology, 2007). 


\section{Russia's Legacy and International Cooperation}

It is not sufficient to merely take 1991 as the official starting point for the modern set of Russian policies regarding international cooperation. Rather, the issue dates back to the late 1980s, the era of Perestroika, when the new Soviet political leadership under Mikhail Gorbachev made their first modest attempts to begin dialogue with Western nations, thanks to the new détente in relations with the United States and Western European countries. This period witnessed the formulation of several goals that in different combinations are still of great importance for Russia. The gradually opening Soviet state emphasized international cooperation in order to commercialize some Soviet technologies and products (for example, space launch services) and to obtain legitimate access to Western technological skills and resources - both in the form of joint ventures and the acquisition of technologies - in order to modernize the economy. The collapse of the Soviet Union undermined this policy, but Russia's ultimate need for international cooperation remained.

In the early 1990s in Russia, international cooperation in high technology still existed, but due to the enormous economic problems facing the country it was much more a struggle for survival than a matter of government policy, and the efforts to pursue have a were characterized less by strategic planning than by a semi-chaotic ad hoc approach. ${ }^{3}$ Most importantly, in practical terms cooperation took place in a vacuum of government, corporate, and state companies' policies, with no established models or proper federal regulation, and with no clear goals, even for the medium term.

As most readers will be aware, the Russian economy collapsed, essential infrastructure and production facilities were in ruins, and the human potential of the Russian workforce shrunk dramatically because of internal (from high-technology and science sectors to other sectors of the economy) and international "brain drain." Thus it is not surprising that in these circumstances, even when cooperation was formally successful, it neither stimulated innovation nor provided needed resources for modernization or development. Russian enterprises were ready to sell almost everything, even important technologies or critical equipment, for a very low price. And multiple alleged cases of corruption and mismanagement made this "zero-sum game" much less effective, without even mentioning the dire macroeconomic and political situation in the country that made the pursuit of any complex economic activities virtually impossible.

The mid-1990s brought about a partial stabilization of the economy, which enabled Russian high-technology enterprises and facilities to reestablish economic ties with

3 On the history, structure, and problems of post-Soviet Russian science and technology policy, including different internationalization issues, see Loren Graham and Irina Dezhina, Science in the New Russia: Crisis, Aid, Reform (Bloomington, IN: Indiana University Press, 2008). A potential model of international cooperation and foreign aid for Russian science (which is still very typical, even if it is not the same as true collaboration) can be seen in Irina Dezhina, "American Science Foundations in Russia as Driving Forces of International Transfer in Knowledge and Professional Skills," ISTR Conference Working Papers, vol. III, Cape Town Conference 2002; available at www.istr.org/conferences/capetown/volume/ dezhina.pdf. 
partners elsewhere in the world and harmonize some essential functions. Together with rising demand for high-technology products in world markets, this era of stability resulted in the modest intensification of international cooperation. In turn, it made it possible for a considered conversation about international cooperation issues to take place among Russian elites, which led to the formation of ad hoc national policies and concepts for the role, place, and direction of international cooperation in high-tech and medium-high-tech industries. This process culminated in a framework document, the "Concept of National Policy of the Russian Federation in Science and Technology Cooperation Area (for the period of 2000-2005)," which was signed on 20 January 2000 .

It should be mentioned, however, that there is still widespread opinion that Russian elites in this period were mostly preoccupied with the fight for control over property, public resources, and political clout, and that they did not concentrate serious attention on science, technology, or modernization issues. But the relatively large number of international high-tech cooperation projects undertaken by several state-owned companies indicates that at least some leaders in Russian society engaged in the formulation of specialized regulations, contracts, and operational activities had formed a long-term vision for collaboration, based on experience. And the appearance of a specialized strategic document on the issue provides material proof that the conversation was underway, even during the heyday of the emerging oligarchs.

\section{A New Direction}

The concept document fixed a vision of the role of international science and technology cooperation in the context of Russia's overall science and technology policy, and declared several main directions and goals for such collaboration. International cooperation was named as one of the most important elements of science and technology policy, and was identified as a key instrument for the modernization and restructuring of the Russian economy on a foundation of innovation, and for the integration of Russia into the global market as a high-tech power. In order to achieve these goals, the concept document stated that cooperation with Western nations would be necessary in commercializing technologies and would help Russian companies to find a place in global value chains, attract investments, etc. The dialogue with developing nations was aimed at getting access to their markets and financial resources (through cooperative efforts and joint ventures).

This strategic, theoretical document genuinely reflected some actual long-term goals and directions of cooperation (it could be seen that in many cases it was structurally built upon decades-old ideas that were still in effect in certain circles). However, the practical policies and models that proceeded from this document were generally

4 See the original text of the document on the archive version of the Ministry for Science and Technology's website (later reorganized as the Ministry for Science and Education): "Kontsepsia gosudarstvennoi politiki Rossiyskoy Federatsii v oblasti mezdunarodnogo nauchotekhnicheskogo sotrudnitchestva (na period 2000-2005 godov)"; available at www.minstp.ru/ 011.htm. 
quite different. Never clearly fixed in political documents, they can be traced instead to the organization of practical efforts.

First, even though a very general long-term vision existed, a clear set of goals and comprehensive policies to support this vision were still absent. The medium-term goals were obvious: saving industries and providing resources for further development. But if we set aside some cursory mention of taking part in global supply chains, the postsurvival goals, forms, and even areas of operations for future Russian high-tech companies were left remarkably unclear.

Moreover, unlike the approach of stimulating existing and new points of growth (as was the practice in Japan, South Korea, and Finland), Russian political practice placed priority on only a few groups of successful industries. From the outset, practical concepts in high-tech international cooperation placed particular emphasis on the "hard" and state-owned (totally or partly) areas of high-technology research and production: defense, aerospace, and the energy/power generation sector (including nuclear reactors). The reason for this emphasis was a historical legacy of the structure of Russia's technology industries.

Russia's most significant high- and medium high-technology potential (in terms of technologies, competences, human resources, and production facilities) was concentrated almost exclusively in those sectors. But the collapse of the Soviet Union led to a dramatic drop in federal investment in all these sectors, and in federal acquisitions (prior to 1991, the only source of revenue) of their goods and services. And early Russian businesses were oriented almost exclusively on low-technology projects (primarily focused on resource extraction) and were neither able to acquire and restructure those enterprises, nor to formulate sustainable demand for national civilian or dual-use hightech products.

The only two successful private high-tech sectors (according to the OECD classification) of the Russian economy were information technology-based on the Soviet Union's traditional strengths of math and science education - and telecommunications, a sector that has experienced tremendous growth since the late 1990s. ${ }^{5}$ Between these two, information technology companies were more export-oriented. ${ }^{6}$ The international strategies pursued by Russian telecom companies (namely AFK-Sistema, VimpelCom, and MegaFon) evolved in the early 2000s, and were oriented first on entering markets within the Commonwealth of Independent States (CIS), and then those of other nations. In the medium high-technology sector there were (and are) several strong energy-machine companies (Siloviye Mashiny, etc.) that are also competitive on international markets and highly export-oriented.

This situation clearly affected the official political concepts and strategies of the Russian political leadership. On one hand, the Kremlin faced a very troublesome (but still potentially promising) situation with respect to the economically critical and inno-

5 Statistical data presenting the state and dynamics of technology innovation in Russia, export activities, R\&D intensity, etc., can be found in special editions of Indicatory innovatsionnoy deyatelnosty. Statisticheskiy sbornik (Moscow: GU-VShE, 2008-09).

6 See "From Russia with Technology?" Business Week (30 January 2006). 
vation-dependent "hard" sectors of the economy, where the absence of federal money and weak internal demand made international cooperation the only way to provide cash flow for operations and investments for modernization and development. And it was mainly the state-owned sector (along with some energy machinery enterprises) that made the problem even more appealing in socio-economic terms, while simultaneously rendering it more manageable for the government. Inside these sectors, most attention was concentrated on enterprises that were already dynamically developing international contacts, which made the choice easier. On the other hand, there was a successful private IT business sector that was fulfilling internationalization strategies using its own competitive strengths, and did not rely on significant lobbying efforts in attempts to gain more influence on decision-making processes (unlike resource companies). Finally, there were very limited resources available to high-technology firms, since the economic situation in Russia was far from perfect, and significant amounts of investment were channeled to oil, gas, and other natural resources industries.

In this situation, and (supposedly) due to the lack of any experience with publicprivate partnerships, the Russian government concentrated in its international policies mostly on a group of "hard" technologies, promoting the export of Russian defense and energy machinery products, while either stimulating or simply not blocking foreign investments and joint ventures in aerospace and other sectors. In spite of this general atmosphere of neglect, the IT sector did receive some support in its internationalization efforts, especially regarding the expansion of telecom companies in CIS markets.

\section{Examples of Successful Cooperation}

From the middle of 1990s onward, two major de facto complementary directions evolved with respect to international cooperation that were formally in line with the theoretical propositions later fixed in the concept document as an artifact of elite consensus. The first and most visible one was an aggressive marketing effort dedicated to promoting Russian high-technology (mostly defense) products in developing markets in order to supply these enterprises with much-needed cash. These efforts saved many critical industries from total collapse, and provided some firms with life-saving contracts. Major defense deals with China, and later with India and other Asian nations, resulted in the rapid growth of Russian high-technology defense exports, which reached USD 4 billion in 2000-01.

The second development was the emergence of close cooperation with Western multinational corporations. Unlike the early 1990 s, when cooperative efforts were driven by desperation, this wave had several different rationales. The first was the fragmentation of the Russian high-technology sector due to the collapse of numerous industries in the early 1990s, combined with some gaps in Russian technological development since the Soviet era (in areas such as microelectronics and some others). Global markets demanded more sophisticated and up-to-date products, resulting in rising acquisitions of Western components and systems for Russian defense, space, and energy machinery products. This practice was gradually transformed in the formation of supply chains. For example, the Sukhoi and Mig corporations used French avionics 
in all export versions of their fighters and training jets; several other devices and even engines were integrated into different Russian defense technology platforms. Capitalizing on this new experience, Russian state-owned companies also tried a materially new form of cooperation: development and design partnerships. Although such partnerships were formed mostly in areas of secondary importance, as a model of cooperation they were seen as cutting-edge, since the model strengthened not only the technological potential of future products, but their marketing as well. One clear sign that the Russian mindset regarding collaboration was beginning to change was the development of the advanced military trainer jet fighters MIG-AT (carried out in cooperation with the French aerospace firms Snecma, Sestante, and others) and the Yak-130UBT (developed in cooperation with the Italian firm Finmeccanica).

The second driver of this new mode of cooperation was the mutual desire on the part of both Russian and Western companies to combine their technological expertise and products in cooperative projects on the world market (for Russian companies, the main rationales here involved commercialization and rising investments). Since the middle of the decade, several Russian high-technology enterprises initiated or took part in different successful cooperative projects. For example, RKK "Energia" and other national space enterprises became major or important players in Sea Launch, International Space Launch, Starsem and other projects and cooperative ventures for space launch services. Research and development cooperation was established as well. For example, in 1998, the U.S.-based Boeing Design Center appeared in Russia, ${ }^{7}$ while a symmetrical but less extensive effort was made by the European consortium Airbus.

Many of these activities were still forced or semi-forced in nature, and were provoked by the insufficient level of federal funding. But, whatever the reasons behind it, this new experience was still a useful one. It helped Russian companies and some state agencies to formulate, if not full-fledged strategies, then at least modes of fruitful cooperation, define areas and basic parameters of partnerships, increase the effectiveness of their activities, accommodate their practices to the realities of the global market, and form an extensive (in comparison with previous years) network of alliances and partnerships with foreign nations and MNCs.

\section{The Emergence of Cooperation Strategy}

Combining conceptualizing and practical experience, at the beginning of the new millennium Russia was ready for the formulation of a new real strategy. And rising oil and gas prices provided the resources to fund this process, making economically feasible

7 See the official website of the Boeing Design Center: http://www.boeing.ru/ ViewContent.do?id=41622. See also several articles on this cooperative project: Sabrina Tavernise, "Boeing's Russian Edge," New York Times (26 May 2001), available at www.nytimes.com/2001/05/26/business/boeing-s-russian-edge.html?pagewanted=1; and Stanley Holmes, "Boeing's Global Strategy Takes Off," Business Week (30 January 2006), available at www.businessweek.com/magazine/content/06_05/b3969417.htm. 
both ambitious plans in the high technology arena and a new era of cooperative policies.

In the early 2000s, a process was seen to be at hand that was labeled in Russian political narrative as the "transfer to the innovation path of development." And among the institutional and economic reforms that have taken place since 2002, the international cooperation strategy, building upon the experience of previous years, was considered to be one of the key instruments. In turn, rising investments in R\&D and modernization led to increased capabilities, which made international cooperation more attractive to foreign partners.

Despite the fact that it was never fixed in an official, finalized form, in the middle of the 2000s new federal strategy and policy began to form around the issue of science and technology. Unlike the period of intense fundraising in the 1990s, when any partners willing to pay were in reality often treated equally, Russia's new financial independence led to a prioritization of (or, more correctly, a functional differentiation among) partnerships and international cooperation as a whole. Also unlike the 1990s, a new long-term goal was proclaimed: raising the profile and competitiveness of Russia's strongest high- and medium high-tech global corporations in selected areas. Not surprisingly, during a new round of science and technology policy transformations, several large state holding companies-labeled "State Corporations"-were created in aviation, nuclear, and non-aviation defense industries, among others.

Conceptually and logically the most important step was pursuing cooperation with Western MNCs in order to get new investments, gain access to technologies, and form joint enterprises for developing and marketing new and existing high-technology products. The most visible processes of cooperation were going on in the aerospace industry. For example, several deals were made with Boeing and Airbus regarding the production of parts for aircraft, rebuilding A320 passenger airliners into cargo aircraft, etc. Roskomos entered a joint project with Arianespace and the European Space Agency on the modernization and launch of Soyuz rockets from French Kourou, and a number of other projects were initiated as well. ${ }^{8}$ Russia even sold 10 percent of the shares of Irkut Aviacorporation to EADS, and acquired about 5 percent of EADS shares in an attempt to tighten dialogue and coordinate strategy formation.

Although at least some of these deals could be viewed as a mere continuation of past trends, the situation in the defense sector and the level of cooperation in the civilian nuclear industry clearly indicates that a new political model for international cooperation had emerged. In the nuclear sector, the dynamism of the Rosatom corporation was triggered and further stimulated by a series of major energy deals with China and India around construction of nuclear power stations. The corporation formed a de-facto

8 See, for example, Jonathan Amos, "European Spaceport's Sky-high Ambition," BBC News (7 March 2008); available at http://news.bbc.co.uk/2/low/science/nature/7278409.stm. See also, on the official website of Arianespace, "Shipment of First Two Soyuz to French Guiana Readies Arianespace for the Growth of its Launch Vehicle Family," 7 November 2009; available at www.arianespace.com/news-soyuz-vega/2009/2009_11_07.asp. 
alliance with Siemens, ${ }^{9}$ initiated extensive consultations on new nuclear technologies and market cooperation with Toshiba and some other companies, and formed technological joint venture with Alstom (production of turbines). ${ }^{10}$

Even more important was the case of the defense sector. Being traditionally the most conservative sector in the Russian economy regarding international cooperation and partnerships, defense and military industrial officials finally partially gave up their "not-invented-here" and "not-produced-here" approaches and forged several deals on technology and products acquisitions with Sagem, Thales, and some other companies.

Finally, a game-changing effort appeared, signaling the birth of a revolutionary (for Russia) new model of global cooperation and outsourcing: Sukhoi's affiliate GSS regional civilian jet project, labeled the SSJ-100 (before that RRJ). Companies from different countries took part in the project: the French firms Alenia and Snecma became GSS's partners; Boeing was chosen to provide consultancy and market expertise; Thales, Parker, Liebherr, and others were engaged in production activities; Snecma and Russian Saturn jointly developed engines; and Finmeccanica decided to provide marketing services. GSS itself became primarily a systems integrator for the project. The new paradigm was especially visible since Sukhoi is still a state-owned company, and a leading Russian producer and exporter of high-tech defense products, including fighter jets.

The other most important direction was Russia's policy toward the developing world. In the eyes of Russian elites, if in cooperation with Western MNCs Russia could play the role of at best an equal or at worst a minor partner, in dialogue with developing countries Russian companies were eager to fill the role of major players. Providing their own technologies and working as systems integrators (on Russian technology platforms) for complex solutions, offering R\&D partnerships and sharing some technologies, Russian businesses theoretically were eager to achieve much-needed "critical mass" in developing markets in pursuit of sustained growth as a global players. In some respects this vision was realistic, especially since Russia secured positive ties with many developing nations' elites, and the rush to modernize military and civilian infrastructure guaranteed stable growth of markets and demand. ${ }^{11}$ In addition, successes in emerging markets were supposedly seen as an additional advantage in providing even more intensive and extensive dialogue with Western MNCs. However, partnering with developing nations did not only take the form of sales to developing

9 See Philip Bethge, Dinah Deckstein, Wladimir Pyljow, and Matthias Schepp, "Siemens Eyes Russian Nuclear Revival," Business Week (22 May 2009); available at www.businessweek.com/globalbiz/content/may2009/gb20090522_165515.htm.

10 See the news from the Russian information websites Finam.ru and RBC Daily, at www.finam.ru/analysis/investorquestion0000116BD2/default.asp and www.rbcdaily.ru/ 2008/06/25/industry/355154, respectively.

11 On Russian high-tech defense export policies, their evolution and main directions, see A.L. Rybas, ed., Voenno-tehnicheskoe sotrudnichestvo Rossii s zarubezhnymi gosudarstvami: analiz rynkov (Moscow: Nauka, 2008); and SIPRI Yearbook 2008: Armaments, Disarmament and International Security (Stockholm: SIPRI, 2008). 
markets. Instead, with some of the more advanced partner nations - primarily IndiaRussia declared the formation of so-called "technology alliances" in order to use their technological expertise for mutual benefit. ${ }^{12}$

So, as in the previous decade, this new strategy was twofold, but was now much better balanced and coordinated, with both prongs of the strategy being aimed at mutually reinforcing each other and addressing several of the most important problems facing the Russian high-tech industry. Perhaps even more importantly, there was a clear set of goals: the elevation of "national champions" (in a few selected areas), closely tied to their foreign counterparts by a network of cooperative agreements; attracting foreign technology-oriented investments for industry modernization; increasing access to world markets; and finding preferable market niches. The strategy was quite reasonable and potentially (if constantly updated and modernized) successful.

\section{Legacies of Resistance}

But the realization of this new policy was suddenly partially blocked by unexpected factors. The problem was that, while supporting the globalization of Russian corporate giants and forging international alliances and partnerships, Russian elites found themselves not yet ready to adopt the globalized vision and create truly transnational enterprises. Transferring production lines and some other functions to other countries, outsourcing (sometimes even for companies in Russia itself), extensive international partnerships - in the eyes of Russian officials, all these activities should operate only within clear limits. In their view, almost all critical systems, components, and systems integration should be done in Russia. And because the targeted corporations were mostly still federal property, this new vision undermined the realization of a possibly positive scenario.

The reasons behind such policies were both rational and irrational. There were some understandable socio-economic and political sentiments behind the resistance to true transnational partnership. In particular, restoring the scope of production activities at domestic facilities was seen as the only way to revitalize Russia's industrial complex. This goal combined with concerns about keeping high-tech jobs in Russia and securing existing supply chains to lend credence to these arguments. In addition, the fact that the most visible technology skills possessed by Russian companies were concentrated in several very "sensitive" areas of defense, aerospace, and nuclear power should also be taken into account. In many cases, foreign localization of such facilities or supply chains was undesirable, as was the conduct of R\&D outside national borders. From this point of view, from the very beginning the answer to the "globalization of operations" challenge was not so clear.

12 For more on this issue, see Ivan V. Danilin, "International Technology Polices and Multipolarity: A Case of Russian 'Technology Alliances' Strategy," paper presented at the annual meeting of the ISA-ABRI Joint International Meeting, Pontifical Catholic University, Rio de Janeiro Campus (PUC-Rio), Rio de Janeiro, Brazil, 22 July 2009. 
But, as the Sukhoi example demonstrates, in the future a smooth extension of competences and specializations (to civilian or defense areas) would be possible. And this case also showed that it was possible to prevent leaks of sensitive critical technologies. More to the point, some functions and facilities oriented toward global markets - even some in the defense sector-could have been transferred without any problem even in the early 2000s. This is especially true since some of the components and systems for export products are already imported by Russian companies, several licenses were sold to China and India, and the joint R\&D and production company BrahMos, which builds cruise missiles, operates in India. However, in spite of such experience, this logic did not transform the vision of elites, and was not extended to other sectors of the economy.

Appeals to the "Chinese" model were also irrelevant. China targets different market niches, and most Chinese high-tech production is due to foreign contracts or MNCs' affiliate activities. It also has a much cheaper labor force, which makes it a perpetually attractive partner for foreign corporations.

These contradictions help to identify the second reason motivating Russia's globalization skeptics: some political elites hold a fundamentally different vision of how Russia and Russian companies should position themselves in a long-range perspective in global markets, and how should they organize their high-technology business operations as global players. Basically, the idea was that "Russian" high-tech products should be produced in Russia, and that the "over-internationalization" of R\&D and production could lead to vulnerabilities of supply chains and the loss of critical technologies and know-how.

The explanation of this "internationalization paradox" is rooted in Russian officials' experience in the Soviet system. Since the early years of the Soviet era, the "mobilization model" of science and technology activities, calling for the concentration of critical resources in selected areas based on exclusively national efforts and resources was used to realize and advance high-tech and large-scale complex technology projects. One reason for that was the practical isolation of Soviet technological enterprises from their counterparts in other developed nations because of the polarized geopolitical environment. The other reason, also with its roots in geopolitical realities, was a practical and ideological need for developing all essential national science, technology, and production facilities and resources only within the national borders, in order to be independent from all other nations in all areas related to critical, "strategic" directions of economic and defense development. Keeping all important design and production elements within the nation's borders was considered as the only guarantee of the independence and sustainability of these branches of industry and the economy.

For decades, this "introverted" mobilization strategy was used to solve different problems: from the development of nuclear weapons to the creation of a domestic automobile industry. And even when the Soviet government emphasized international technology cooperation with Western nations (for example, the acquisition of Fiat's technology and production facilities for the state-owned VAZ company in the 1960s), it was done in order to create new possibilities for national development. 
During the Soviet era, this forced strategy - if still partially rational, in the face of the practical geopolitical realities of the USSR's existence - transformed into what could be labeled as technology or industrial "nationalism." This nationalism took the form of a strong belief that any technological success achieved by Western nations could be copied better or improved by Soviet industry, and that in all cases (except unimportant ones) the Soviet Union should do everything by itself. Of course, in practice the Soviet elites were much more pragmatic, e.g. the acquisition of Western gas compressor machinery for the natural gas pipeline to Germany in the $1980 \mathrm{~s}$, or the secret deal with Toshiba for technology that made Soviet submarines run much more quietly.

Although the realities of the bipolar Cold War environment were no longer relevant after 1991 - both in terms of isolation and the need to secure Russia's national potential in almost all important areas - the old model of thinking survived among at least some groups of elites, and to a quite strong degree. And special interest groups played on this familiar mindset in lobbying for additional federal money. Some populist motives could be seen as well in discussions about employment guarantees and attempts to stoke popular ambitions to reestablish Russia as a global technology power.

For almost a decade this vision was alive but practically unrealistic, but the wave of new oil and gas money that made Russia more independent and wealthy brought with it a set of familiar old words back into the Russian lexicon. For example, even the SSJ100 project is still dismissed by some groups as not being a "real Russian" project, because most of the plane's parts and components are produced by foreign companies. In this environment, the idea of a truly global Russian high-tech corporation had no chance for success.

Simultaneously, some politicians, scientists, and special interest groups were proclaiming that the level of Russian technology (despite the disruptive events of the 1990s) is still so high that the nation could provide technology and innovation breakthroughs with its own resources - a new incarnation of the mobilization model —or with only supportive partnerships with foreign companies. In spite of the existence of very limited resources, the logic affected some decisions in both civilian (promoting national aircraft projects as competitors for some Boeing and Airbus models) and military (attempts to build unmanned aerial vehicles and other intelligence and battle systems) sectors. Ironically, it resulted in the provision of support for some very controversial, expensive, and highly ineffective programs, while other projects-sometimes very promising ones, such as reusable rocket vehicles, the Clipper small space shuttle, new space stations - were either suspended or effectively terminated.

This new "innovation nationalism" logic also affected the mode of partnerships with Western MNCs, although in a very specific way. On one hand, after successful cooperation experiences with Boeing, Finmeccanica, Lockheed Martin, and other companies, the Russian government became confident that Russia's national technologies are very attractive to foreign investors, and thus are potentially very lucrative. That led to the suggestion that these foreign firms would even be willing to play the role of supporting partners for Russia-led projects and joint ventures. 
On the other hand, some (but not all) large foreign investments in strategically important industries were de facto considered as potentially harmful. Russian officials suspected that foreign MNCs would try to steal critical technologies or even disrupt production facilities in order to eliminate competition for their own projects. One of the most visible examples of this mindset was the Russian government's blocking of the further acquisition of shares of the PMZ aircraft engine enterprise by the U.S. aerospace firm Pratt \& Whitney, despite the breakthrough role played by the partnership in modernizing the PS-90A engine.

Of course, there still were exceptions, such as SSJ-100, or civilian nuclear projects. But the dominant view was changing in a different way. The process reached its culmination in a new law, signed by then-president Vladimir Putin in 2008, restricting the potential share that foreign investors could purchase in a broad range of strategic enterprises to under 50 percent. Considering Russian economic realities and the broad range of sectors that were lumped together under the "strategic industries" umbrella, this decision was too harsh. It was not surprising that even Finmeccanica, a very loyal partner of Russia, asked Putin to change the rules of the game, a request to which the government did not respond. ${ }^{13}$

\section{Winds of Change}

Paradoxically, the fresh air that has been introduced into the new Russian politics of high technology was blown in by the global financial crisis. A new set of crisis-driven financial restrictions raised questions about the rationality and adequacy of resource allocations, the accountability of huge national projects, and the viability of state corporations. In this light, the failure of many innovative initiatives and policies became clear. Some disappointing failures in national high-technology programs - mostly in the defense area-also prompted changes (or at least modest alterations) of minds, even among those groups within the military and intelligence elites who were previously highly skeptical of international cooperation. Almost everybody was sure that the previous mode of high-technology strategy was obsolete.

In this context, since the beginning of 2009 the Russian government has returned to a more balanced and cooperation-oriented strategy. A deeper alliance with Siemens was developed in a variety of areas, acquisitions of Israeli UAV technologies and a French Mistral military ship and production technology were negotiated, and numerous other projects were started in order to compensate for previous failures.

Even the language used by politicians changed. While still focusing on strengthening Russia's own innovation potential, the nation's political elites again emphasized the role of foreign competences and actors in the process of modernization. For example, in his programmatic Internet article "Russia, go ahead!" ("Rossiya vpered!"), Dmitry Medvedev declared: "The most favorable conditions would be granted to foreign companies and scientific organizations for creating in Russia research and design

13 See an article published by the Russian RIAN news agency, available at www.rian.ru/ company/20080521/107953647.html. 
centers...."14 This argument was further developed by Vladimir Putin during a government session focused on foreign investments in Russia, on 3 February 2010: "Our main goal ... [is] to diversify our economy, and of course we will strive for stimulating companies of foreign partners that would work on directions that are of key importance for us." $" 15$

A long path of Russian concepts, from modest pro-modernization and pro-commercialization cooperation ideas to a vision for extensive partnerships designed to rebuild the Russian economy on a foundation of innovation and maximize integration in global markets indicates that, although change is taking place too slowly, the new realistic conceptual and political approaches are nevertheless evolving.

A more problematic aspect is that, as the experience of the 2000s showed, Russia's approach to science and technology is still based in some important functional aspects on the same structural elements of the old, outdated policies of the Soviet past. In this situation, policies tend to fluctuate around several poles of ideas, periodically returning to one or another depending on the economic situation. In harsh economic times, elites become more favorably disposed toward cooperation, looking for external resources for national modernization while still considering these policies as forced, and thinking that "normal" innovation policy models should be more nation-oriented. And in the absence of large-scale support for private businesses, since state corporations are key players in national high-tech strategies, the sector overall is strongly affected by these political sentiments.

The reasons for the reproduction of the existing "innovation nationalism" vision or its modifications are numerous and interdependent. First of all, there exists a very low level of competition of ideas among elite groups, who assess ongoing processes primarily based on personal experience, which are often shaped by an entirely different set of challenges from previous decades. Another issue is the continued influence of special interests groups, which are oriented toward getting more budget resources. At the same time, a lack of effective communication (or, sometimes, a lack of willingness to communicate) with rational pro-internationalization actors both in private and public sectors is a continuing problem as well. The specifics of Russian R\&D and innovation policy are also critically important, and serve to perpetuate antiquated points of view. These policy areas are so much affected and complicated by different internal factors - fragmentation, selectivity of efforts, implementation gaps, etc.- that even the

${ }^{14}$ Dmitry Medvedev, "Rossiaya vpered!" Gazeta.ru (10 September 2009); available at www.gazeta.ru/comments/2009/09/10_a_3258568.shtml.

15 "Predsedatel Pravitelstva Rossii V.V. . Putin provel zasedanie Komissii po kontrolu za osushestvleniem inostrannih investitsiy v Rossiskoi Federatsii," 3 February 2010; available at www.government.ru/docs/9302/. See also, for example, an interview with Vladislav Surkov, who is considered to be one of the chief Kremlin "ideologists": "Chudo vozmozno', - Vladislav Surkov, perviy zamrukovoditelya administrtsii prezidenta, zampredsedatel komissii po modernizatsii," Vedomosti (15 February 2010); available at www.vedomosti.ru/ newspaper/article/2010/02/15/225543. 
brightest ideas may not influence the overall situation. ${ }^{16}$ On the contrary, this state of decision-making makes an "easy" and "obvious" decision, such as "innovation nationalism," more affordable, and renders the lobbying of special interest groups more effective.

So the question remains: are there new effective strategies that could be widely adopted and implemented by the current generation of political elites? It seems that Russian elites are not totally ready to give up some of their customary attachment to "innovation nationalism"; the elimination of jobs in Russia in crisis times is considered to be intolerable (which is understandable), and there are no ideas of how to compensate for the "export" of Russian jobs to other countries with new high-tech employment. Highly internationalized supply chains are still mistrusted, as they are thought to render Russia strategically vulnerable. Worst of all, if new efforts due to implementation gaps are not effective, it will adversely (but not tragically) affect current policies and their conceptual basis. Still, the emergence of a slightly more rational and prospective vision for the role and place of international cooperation in high technology, and the moderate renewal of enthusiasm for dialogue with leading players in this area gives hope that, at least in some areas, positive changes may finally reverse negative trends.

16 On problems and structure of Russian science and technology policy, see Irina Dezhina, Gosudarstvennoye regulirivaniye nauki v Rossii (Moscow: Magistr, 2008); Loren Graham and Irina Dezhina, Science in the New Russia; V.V. Ivanov, N. I. Ivanova, et al., eds., Natsionalniye innovatsionnie systemy $v$ Rossii $i v$ ES (Moscow: Nauka, 2010); and O.G. Golichenko, Natsionalnaya innovatsionnaya systema $v$ Rossii: sostoyaniye i puti razvitiya (Moscow: Nauka, 2006). 


\section{Bibliography}

Amos, Jonathan. European Spaceport's Sky-high Ambition. BBC News, 2008.

Bethge, Philip, Dinah Deckstein, Wladimir Pyljow, and Matthias Schepp. "Siemens Eyes Russian Nuclear Revival." Business Week (2009).

Danilin, Ivan V.. International Technology Polices and Multipolarity: A Case of Russian 'Technology Alliances' Strategy In paper presented at the annual meeting of the ISA-ABRI Joint International Meeting. Rio de Janeiro, Brazil: Pontifical Catholic University, 2009.

Dezhina, Irina. Gosudarstvennoye regulirivaniye nauki v Rossii. Moscow: Magistr, 2008.

Golichenko, O. G.. Natsionalnaya innovatsionnaya systema v Rossii: sostoyaniye i puti razvitiya. Moscow: Nauka, 2006.

Graham, Loren, and Irina Dezhina. Science in the New Russia: Crisis, Aid, Reform. Bloomington: IN: Indiana University Press, 2008.

Holmes, Stanley. "Boeing’s Global Strategy Takes Off." Business Week (2006).

Indicatory innovatsionnoy deyatelnosty. Statisticheskiy sbornik. Moscow: GU-VShE, 2009.

Medvedev, Dmitry. Rossiaya vpered!. Gazeta.ru, 2009.

National Science and Engineering Indicators 2010. Arlington, VA: National Science Board, 2010.

OECD Reviews of Innovation Policy. China: Synthesis Report. Paris: OECD, in collaboration with the Chinese Ministry of Science and Technology, 2007.

OECD Science, Technology and Industry Outlook 2008. Paris: OECD, 2008.

OECD Science, Technology and Industry Scoreboard. Paris: OECD, 2009.

Predsedatel Pravitelstva Rossii V. V. Putin provel zasedanie Komissii po kontrolu za osushestvleniem inostrannih investitsiy v Rossiskoi Federatsii., 2010.

Rybas, A. L.. Voenno-tehnicheskoe sotrudnichestvo Rossii s zarubezhnymi gosudarstvami: analiz rynkov. Moscow: Nauka, 2008.

Shipment of First Two Soyuz to French Guiana Readies Arianespace for the Growth of its Launch Vehicle Family., 2009.

SIPRI Yearbook 2008: Armaments, Disarmament and International Security. Stockholm: SIPRI, 2008.

Tavernise, Sabrina. "Boeing’s Russian Edge." New York Times (2001).

World Investment Report: Transnational Corporations and the Internationalization of R\&D. Transnational Corporations 14, no. 3 (2005): 101-40. 